Original Articles

\title{
Identification of potential aquaculture sites in solar saltscapes via the Analytic Hierarchy Process
}

\author{
Zara Teixeira $^{\mathrm{a}, *}$, Cátia Marques ${ }^{\mathrm{a}}$, Joice Seleme Mota ${ }^{\mathrm{b}}$, Ana Carla Garcia ${ }^{\mathrm{a}}$ \\ ${ }^{\text {a } M A R E ~-~ M a r i n e ~ a n d ~ E n v i r o n m e n t a l ~ S c i e n c e s ~ C e n t r e, ~ c / o ~ D e p a r t m e n t ~ o f ~ L i f e ~ S c i e n c e s, ~ F a c u l t y ~ o f ~ S c i e n c e s ~ a n d ~ T e c h n o l o g y, ~ U n i v e r s i t y ~ o f ~ C o i m b r a, ~ 3004-517 ~ C o i m b r a, ~}$ \\ Portugal \\ ${ }^{\mathrm{b}}$ Catarinense Federal Institute, 89245-000 Araquari, Santa Catarina, Brazil
}

\section{A R T I C L E I N F O}

\section{Keywords:}

Ecosystem approach to aquaculture

Spatial planning

Site selection

Physical carrying capacity

Saltworks

Mondego estuary

Portugal

\begin{abstract}
A B S T R A C T
The European Commission has identified competition for space as one of the main factors contributing to the stagnation of EU aquaculture production and has recommended coordinated spatial planning, as a mean to identify sites with favorable operational characteristics for aquaculture and lower potential for conflict with other activities. In coastal areas of the Mediterranean, pond aquaculture has emerged as an alternative to salt production in abandoned artisanal Salinas, compromising the delivery of Ecosystem Services in wetland areas. To establish a methodology to estimate the physical carrying capacity for coastal pond aquaculture, and the contribution of the ecosystem to the value of provisioning services from aquaculture, while minimizing the competition for space with solar salt production, we applied a multicriteria-decision making tool (AHP method) to identify priority areas for extensive and semi-intensive aquaculture development in solar saltscapes, taking into account physical factors of ecological and social nature. The study presents spatial allocation scenarios for aquaculture development in the saltscapes of the Figueira da Foz, in the Atlantic coastal zone of Portugal. The physical carrying capacity for the two scenarios presented indicates a potential increase of the area occupied by aquaculture farms in ponds previously occupied by inactive farms and flooded/land filled salterns, whose sites tend to minimize conflict with salt production through avoiding the same water input location and being adjacent to active farms. In conclusion, the approach applied has proven to be successful to manage space competition between aquaculture and salt production, contributing to a sustainable increase of the value of the provisioning of ecosystem services from aquaculture. In future studies, estimation of the social carrying capacity should be combined with the approach followed in this study to improve the definition of the acceptable social limits for aquaculture development in saltscapes.
\end{abstract}

\section{Introduction}

\subsection{Sustainable aquaculture}

The European Commission has identified aquaculture as one of the pillars of the EU's Blue Growth Strategy (EC, 2012) and proposed non-binding strategic guidelines towards the economic, social and environmental sustainable development of aquaculture (EC, 2013). One of the main recommendations is the increase of production through coordinated spatial planning (EC, 2013), as a mean to identify sites with favorable operational characteristics for aquaculture and lower potential for conflict with other activities (Henriques et al., 2017, Gentry et al., 2016). Aquaculture competes for ecological, physical, economic and social resources with other sectors such as fisheries, salt production and tourism (Benessaiah and Sengupta, 2014; Dalton et al., 2017; Gimpel et al., 2018; Paéz-Osuna, 2001).
In coastal areas, competition for space has been identified as one of the main factors contributing to the stagnation of EU aquaculture production (Hofherr et al., 2012; Hofherr et al., 2015). For inland aquaculture, such hurdle may be overcome implementing spatial plans that "take into account the environmental services provided by extensive pond-based aquaculture" in a multi-use context (EC, 2013). Among the possible approaches to this problem is the recovery of wetlands through dual purpose wetlands/ aquaculture ponds (Walton et al., 2015; Paéz-Osuna, 2001) and the recovery of abandoned saltwork ponds (Buestel, 2005; Santulli and Modica, 2009). Both strategies incorporate conservation and extensive aquaculture activities in compliance with the ecosystem approach to aquaculture (EAA) promoted by UNEP and FAO (FAO, 2010). The EAA "is a strategy for the integration of the activity within the wider ecosystem such that it promotes sustainable development, equity, and resilience of interlinked social-ecological systems" (FAO, 2010).

\footnotetext{
* Corresponding author.

E-mail addresses: zara.teixeira@uc.pt (Z. Teixeira), joice.mota@ifc.edu.br (J.S. Mota), acmgarcia@uc.pt (A.C. Garcia).
} 
An EEA strategy, ensuring environmental, economic and social sustainability, can only be put in practice if aquaculture facilities adjust their production to the carrying capacity of the local environment and social context (Ross et al., 2013). "Carrying capacity for any sector can be defined as the level of resource use that can be sustained over the long term by the natural regenerative power of the environment" (Ross et al., 2013). The concept helps defining the upper limits of aquaculture production given the environmental limits and social acceptability.

Although the general views of carrying capacity for aquaculture are based solely on production, they have been developed further into a more comprehensive four-category approach based on physical, production, ecological and social carrying capacity (FAO, 2010; Inglis et al., 2000; McKindsey et al., 2006). The physical carrying capacity has been defined as the total area that can be accommodated for aquaculture in the available physical space. It determines the development potential in any location, taking into account the physical factors of the environment, such as salinity, temperature and infrastructures. From a decision-making point of view, the physical carrying capacity is the first step towards the identification of suitable areas for sustainable aquaculture development, as it is recognized as a broader site selection criterion. The production carrying capacity estimates the maximum aquaculture production at restricted areas, such as farm or delimited regions within a water basin, dependent upon the technology, production system and financial investment. The ecological carrying capacity estimates the magnitude of aquaculture production (stocking or farm density) that can be supported without leading to significant changes to the environment. The social carrying capacity calculates the level (intensity, productive system, etc.) of farm development that can be developed without adverse social impacts.

\subsection{Multicriteria Decision-Making for aquaculture}

The success of an aquaculture project depends largely on the proper selection of a site to develop a fish farm or hatchery. This involves seeking for optimal solutions to multiple alternatives, frequently managing conflicting issues between stakeholders with conflicting objectives. A valuable tool to select the "optimal solutions" is the Multicriteria Decision-Making (MCDM) framework (Communities and Local Government, 2009). MCDM embraces a collection of approaches that support complex decision-making situations helping stakeholders to explore decisions that matter (Mendoza and Martins, 2006).

For the aim of aquaculture development, MCDM methods have been seen variably as (i) a decision-support system that integrates biological, ecological and socio-economic values (Mamat et al., 2014; Micael et al., 2015; Wijenayake et al. 2016); (ii) an impact and risk assessment tool (Falconer et al., 2013; Rekha et al., 2015; Seekao and Pharino, 2016); and (iii) an approach to elicit stakeholders' preferences on key issues for the development of aquaculture (Lembo et al., 2018). MCDM methods have frequently been used in spatial explicit models, supporting site suitability assessments (Hossain et al., 2009; Mamat et al., 2014; Micael et al., 2015).

One of the most widely used MCDM methods is the Analytic Hierarchy Process (AHP) (Saaty, 1980; Altuzarra et al., 2007). AHP considers qualitative and quantitative information and combines them by decomposing ill structured problems into systematic hierarchies by deriving ratio scale weights and priorities through pairwise criteria comparison (Chen et al., 2008; Saaty and Vargas, 1991). Advantages of this method arise from (i) the binary comparisons between just two objectives, which reduce the cognitive burden (Hall et al., 2004); (ii) the calculated numerical weights, which introduce some objective judgement to subjective processes (Mau-Crimmins et al., 2005); and (iii) the flexibility of the method, which allows decision-makers to structure the decision problem according to the specific characteristics of the area (Hossain et al., 2009). The method has nonetheless been criticized mainly due to the problem of rank reversal, i.e., the changes that may occur in rankings when adding one new alternative (Robins,
2004). Despite its pitfalls the method is suitable for individual and group decision making (Yavuz and Baycan, 2013; Sutadian et al., 2017; Morgan, 2017) and has been applied in many research fields, including nature, economy and society (Saaty, 1996; Latinopoulos et al., 2012; Chen et al., 2014; Zhang et al., 2014; Li et al., 2016; Ying et al., 2007). In particular, the AHP method has been applied in aquaculture site selection studies (Falconer et al., 2016), frequently coupled with geographic information systems (Hossain et al., 2009; Radiarta et al., 2008; Rekha et al., 2015).

\subsection{Aquaculture in salt production areas}

Salinas, i.e., solar saltworks, are mainly found in climate regions and have been shaping Mediterranean coastal landscapes for centuries (Walmsley, 1999; Balsas, 2016), within the boundaries of estuarine waters, intertidal marshes, brackish saline lagoons and coastal freshwater lagoons (Crisman, 2000). Salinas are highly modified natural and created coastal ecosystems, producing economically viable products (Korovessis and Lekkas, 2009) while playing a critical role in environmental conservation (Crisman et al., 2009).

Artisanal salinas in the Mediterranean have been in continuous decline since the 1950s (Petanidou and Dalaka, 2009), due to changes in the scale of fabrication (Sadoul et al., 1998); prime development land for urbanization, industrialization and tourism (Petanidou and Dalaka, 2009); lack of technological innovation (Coelho et al., 2015); lack of workforce (Balsas, 2016); changes in hydrological regimes (Coelho et al., 2015); and competition for aquaculture (Coelho et al., 2015). As a consequence, abandoned salt ponds have been filled in attempts to create new land for other uses. In Europe, salt ponds have been used for oyster culture in France, since the 17th century (Buestel, 2005); for fish culture in Sicily (Italy), though here most of the fish is reared in reservoir ponds used for the initial stages of salt making (Popescu, 2010); for fish culture in the Bay of Cádiz (Spain) (Yufera and Arias 2010); and also for fish culture in Aveiro, another saltscape in Portugal (Rodrigues et al., 2011). In Aveiro, during the 80's and 90's, fish farms replaced salt exploration at a rate of 13 salinas per year, but then the number and production of fish culture units decreased possibly due to lower investment and foreign competition (Rodrigues et al., 2011). In the Mondego estuary, fish farming increased when Portugal became an EEC/EU member and subsidies were attributed to aquaculture. Currently, local authorities are encouraging the implementation of aquaculture facilities as a mean of local socio-economic development.

The decrease in solar salt production compromises supporting, regulating, provisioning and cultural services in wetland areas, and the cultural identity of an entire generation (Cordeiro and Paredes, 2013; Crisman et al., 2009; Davis, 1999; Davis, 2000; Vieira and Bio, 2011). In recent years, attempts have been made to preserve solar saltworks and artisanal production and to raise awareness to the environmental, cultural and socio-economic importance of this ancient activity (Rodrigues et al., 2011). Simultaneously, aquaculture development has been promoted to support food needs and economic development (EC, 2009). As static water ponds, through the conversion of saltworks to aquaculture farms, are one of the most common water bodies used for aquaculture, the development of this activity in coastal areas is, in some cases, in conflict with salt production activities (Dalton et al., 2017) and wetland management and restoration (Yang et al., In Press). Local authorities have thus a dual problem: how to avoid the decline of solar salt production while promoting sustainable aquaculture development on its all facets: economic, social, environmental and cultural.

The current study is set within the boundary of the Figueira da Foz Municipality, in the Atlantic coastal zone of Portugal, which has been losing its saltworks since the 1970s (ZIR, 2011), and urges for an integrated management plan that considers both the aquaculture and the salt production activity. It proposes a MCDM approach to identify priority areas for semi-intensive and extensive aquaculture development in solar salt production areas. The method allows to estimate 1) 


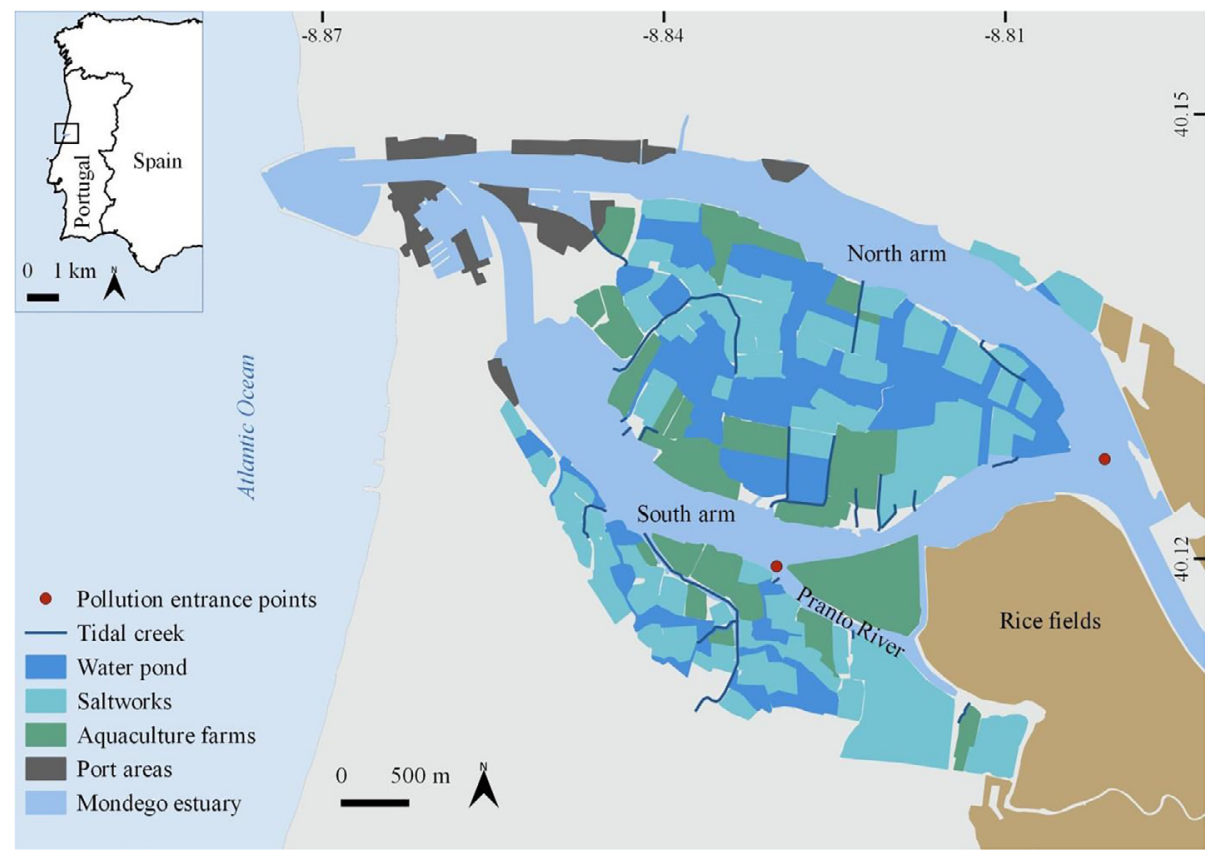

Fig. 1. Study site in the center of Portugal.

the physical carrying capacity for aquaculture, while minimizing the competition for space with solar salt production; and 2) the contribution of the ecosystem to the value of provisioning services from aquaculture by the change in value generated by variations in spatial allocation (Fezzi et al., 2011).

\section{Case study}

\subsection{The Salgado of the Figueira da Foz}

The Salgado of the Figueira da Foz, hereafter Salgado, at the western coast of Portugal, is located within the Figueira da Foz Municipality (Fig. 1). Its area, currently occupying 845.20 ha, is distributed along the Mondego estuary and along the left bank of the Pranto River, integrating three demarcated regions: Ilha da Morraceira, Lavos (south margin of the Mondego estuary) and Vila Verde (north margin of the Mondego estuary) (Fig. 1).

The first records of artisanal salt production in Portugal go back to the fifteenth century (Amorim, 2001), flourishing until the 1970s. By this time a total number of 229 active salterns (each saltwork may comprise more than one saltern) was recorded in the Salgado of Figueira da Foz (Silva and Marques, 2016). Afterwards, the number of salterns gradually started to decline and, in 2016, the National Institute of Statistics pointed to 15 active salterns, occupying a total area of 45 ha (INE, 2017).

\subsection{The Mondego estuary}

The Mondego estuary is an intertidal system divided in two arms: the northern and southern arms. The water depth varies between 5-10 $\mathrm{m}$ (northern arm) and 2-4 $\mathrm{m}$ (southern arm) during flood time; the tidal range varies between $0.35 \mathrm{~m}$ and $3.3 \mathrm{~m}$ with respect to the mean sea level; and the water residence time varies between 1-2 (northern arm) and 3 days (southern arm) (Kenov et al., 2012). The northern arm receives water from the Mondego river, whereas the southern arm receives water inflows from both the Mondego and the Pranto river (Fig. 1), which is artificially controlled by a sluice (Marques et al., 2013) and regulated according to water requirements of the rice fields from the Pranto Valley. A comprehensive study on the Mondego estuary environmental quality has been carried out for more than 25 years.
Studies evaluating the eutrophication symptoms in the Mondego estuary suggested that currently the nutrient balance and status of this coastal system depended both on biogeochemical mineralization processes (Coelho et al., 2004; Otero et al., 2013) and on additional external point and diffuse sources within the south arm or through the Mondego river north arm (Lillebø et al., 2005). The productive agricultural fields are one of the main causes of pressure to water quality and the strongest impacts have been observed in the southern arm of the estuary (Baeta et al., 2011; Dolbeth et al., 2007; Teixeira et al., 2014).

\section{Methods}

As no information was available regarding the current situation of the Salgado, the first step was to characterize the spatial distribution of aquaculture farms and salterns in the Salgado (Fig. 2). Then, the suitable ponds for aquaculture development were identified applying the Analytic Hierarchy Process (AHP), which provided a ranked list of physical factors, allowing us to classify the potential of each pond for aquaculture development based on the weighted relevance of factors (Fig. 2). Once the ponds were classified, the physical carrying capacity was calculated considering a) the current situation (scenario 1) and also b) a highly probable situation (scenario 2) where all aquaculture farms (active and inactive) would be active. Scenario 2 is highly probable because inactive aquaculture farms are exceedingly suitable for aquaculture and some of them still have a valid license for aquaculture production. For the purpose of this work, the aquaculture physical carrying capacity was considered as the total area that the Salgado of the Figueira da Foz can accommodate for aquaculture development, constrained by physical factors. Finally, the provisioning of ecosystem services provided by aquaculture was estimated based on the current situation and on the physical carrying capacity (Fig. 2).

\subsection{Characterization of the current situation}

The current location, number and area of salterns and aquaculture farms was assessed using aerial photography, from the year 2016, provided by Google Earth ${ }^{\circledast}$ and assessed by QGIS ${ }^{\circledR}$ version 2.18 .1 . The status of aquaculture farms (active and inactive) was determined using official registries and the support of local aquaculture farmers. The 


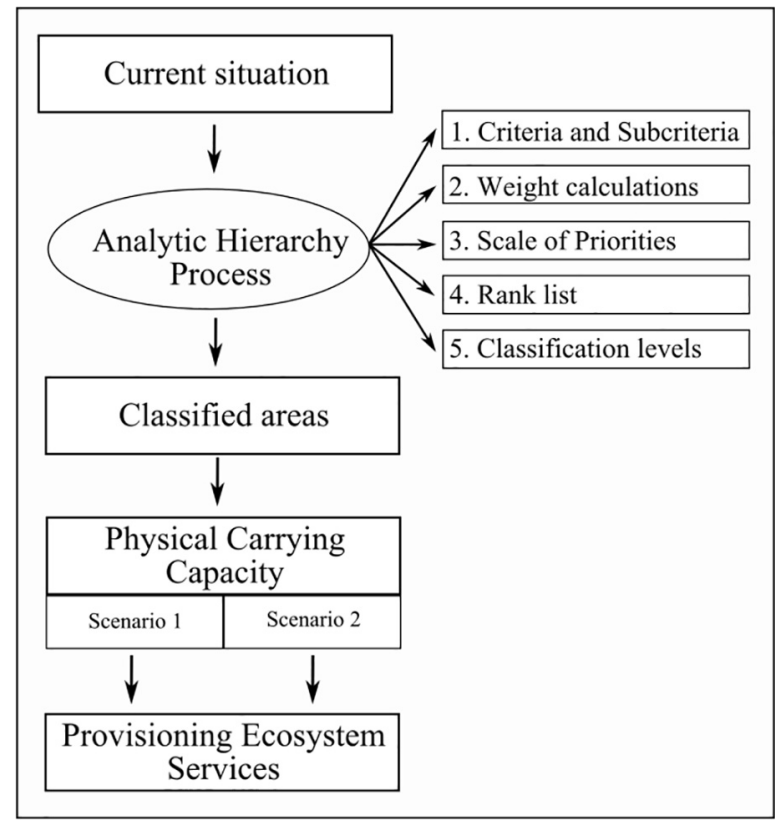

Fig. 2. Diagram of the methodology applied.

status of salterns (active, fallow and flooded/land filled) was determined in the field with the support of local salt workers. The registry of artisanal saltworks is not fully established, due to obstacles related to historical property rights, unknown heirs and/or unconcerned heirs.

\subsection{Determining physical carrying capacity via AHP}

\subsubsection{Selection of criteria and sub-criteria}

Criteria and sub-criteria, in the context of this study, are the physical factors that may favour and/or constrain the development of aquaculture. Physical factors may be of different nature: a) ecological (e.g. water input, water supply source, proximity to water pollution sources); b) biological and operational (e.g. estimated size of area required) and c) socio-economic (e.g. availability of land; availability of transport facilities; distance to saltworks) (FAO, 1984). To attain our goals, a set of ecological and socio-economic factors were selected, based on a thorough knowledge of the study site. The long monitoring program in the Mondego estuary provided information regarding the pollution sources and the hydrodynamic characteristics in the study area (Coelho et al., 2004; Otero et al., 2013; Lillebø et al., 2005; Baeta et al., 2011; Dolbeth et al., 2007; Teixeira et al., 2014; Kenov et al., 2012). Meetings with local salt workers and aquaculture farmers provided information regarding the main constraints and necessities of both activities (Marques et al., 2017). Six criteria, based on ecological and socio-economic physical factors, were established and validated by local authorities as conditions to incorporate in the planning process.

1) Status: The status of each salttern (active, fallow or flooded/land filled) and aquaculture farm (active, inactive) in the Salgado. In order of preference of occupation: 1) inactive farms 2) flooded/land filled salterns and 3) fallow salterns. The highest priority was assigned to inactive aquaculture farms because these already have facilities crucial for the success of the activity, lowering the economic investment needed to implement an aquaculture. Additionally, some of these inactive farms, still have a valid license for aquaculture. Also, it is unlikely that these units would become salt ponds again as they would need a paramount intervention. Next, priority was assigned to flooded or land filled salterns because these ponds lack the conditions for aquaculture, but at the same time have lost their structural characteristics for salt production, which increases both the financial investment for aquaculture and salt production. Fallow salterns were given the lowest priority because they maintain their characteristics for salt production and thus their main priority is for salt production. Active salterns and farms were removed from the analysis as it is unlikely, and not desirable, that they will change its economic activity.

2) Water input: The site where the water is captured. In order of preference: 1) estuary arm, 2) tidal creek, 3) water pond (Fig. 2). The highest priority was assigned to water input from the estuary arm because ponds with this characteristic have higher water availability, than those capturing from tidal creeks or water ponds. Moreover, units capturing water directly from the estuary are located at the edge of the Salgado and, therefore, are less likely to destroy the salterns' protective structures ("motas"). The lowest priority was assigned to water input from water pond, because ponds with this characteristic must share water with neighboring salterns, increasing the potential for conflicts with saltworks over water consumption among farms and saltworks.

3) Water Source: The water course from where the captured water is from: 1) north arm, 2) south arm or 3) Pranto river. The three possible water sources (Fig. 2) have different hydrographic characteristics that determine the nutrient and pollutant dispersion capacity. Facilities whose captured water comes from the north arm have higher preference because this arm shows the higher dispersion capacity (Kenov et al., 2012) and therefore higher water quality. On the contrary, the Pranto River shows the lowest dispersion capacity and is closer to point and diffuse source pollution, showing lower water quality (Flindt et al., 1997; Martins et al., 2001; Kenov et al., 2012).

4) Access: The type of access. In order of preference: 1) vehicles, 2) pedestrian. Most of the trails within the Salgado are poorly developed, not tarred and not prepared for high traffic, if any traffic at all. These are convenient conditions for the artisanal characteristics of salt production in the Salgado, as it discourages new aquaculture farms adjacent to active salterns, but not desirable for aquaculture. Facilities with trail widths large enough for car circulation had higher preference than pedestrian trails for aquaculture development. Only the smallest width of the trail, since the nearest national road until each saltwork or farm, was considered. Pedestrian trails were not removed from the analysis since there is the possibility of widening the access, although not without public investment in infrastructures.

5) Distance to Pollution Source: In order of preference: 1) Long (above $4 \mathrm{~km}$ ) 2) Medium (from $2.6 \mathrm{~km}$ to $4 \mathrm{~km}$ ), 3) Short (until $2.5 \mathrm{~km}$ ). The short distance was defined based on the distance between the two pollution point sources, because we considered equal pollution influence between these two points. The medium and long distance correspond to an increase of $1.5 \mathrm{~km}$. A maximum of $5.5 \mathrm{~km}$ in each arm, from the north arm pollution source until the most downstream pond, was considered. Regardless the water source, water captured upstream the river will have lower water quality due to the proximity to pollution sources. For this reason, facilities downstream the water courses, or in other words, with long distances to pollution sources, have higher preference for aquaculture development.

6) Adjacency to aquaculture farm: Whether the interest area is adjacent to an active aquaculture farm. In order of preference: 1) Yes, 2) No. Adjacent aquacultures reduce the probability of destroying the salterns' protective structures ("motas"), reducing the probability of water infiltration into the salt pans and, therefore, reducing the probability of conflict.

\subsubsection{Determining the ranked list of physical factors}

The AHP is used with two types of measurement, relative and absolute. In the present work the absolute measurements were applied to determine the ranking of the most adequate ponds for aquaculture development. When applying absolute measurement only the main 
Table 1

Pairwise comparison matrix for the main criteria.

\begin{tabular}{|c|c|c|c|c|c|c|c|}
\hline Criteria & Status & Water input & Water source & Access & Distance to pollution source & Adjacency to Aquaculture farm & Weight \\
\hline Status & 1 & 3 & 5 & 7 & 7 & 9 & 0.492 \\
\hline Water input & 0.33 & 1 & 2 & 4 & 4 & 6 & 0.224 \\
\hline Water source & 0.20 & 0.50 & 1 & 2 & 2 & 4 & 0.121 \\
\hline Access & 0.14 & 0.25 & 0.50 & 1 & 1 & 2 & 0.064 \\
\hline Distance to pollution source & 0.14 & 0.25 & 0.50 & 1 & 1 & 2 & 0.064 \\
\hline \multirow[t]{2}{*}{ Adjacency to Aquaculture farm } & 0.11 & 0.17 & 0.25 & 0.50 & 0.50 & 1 & 0.037 \\
\hline & \multicolumn{7}{|c|}{ Consistency Ratio $=0.012$} \\
\hline
\end{tabular}

criteria are pairwise compared to derive priorities for criteria. In this situation, the alternatives, i.e. the sub-criteria, are just rated within the criteria to which they belong. A weighting and summing process yields their overall ranks (Saaty, 1990).

For the pairwise comparison, the free web based BPMSG AHP Online System (Goepel, 2017) was applied to calculate the weight of each factor and to obtain the comparison matrix as well as the index of consistency, known as the consistency ratio (CR). Mathematically the method is based on the solution of an Eigenvalue problem applying the power method algorithm with a fixed number of 12 iterations (Goepel, 2017). The results of the pairwise comparisons are arranged in a matrix, where the first (dominant) normalized right Eigenvector gives the ratio scale (weighting) and the Eigenvalue determines the consistency ratio (CR) (Saaty, 1980).

Seven pairwise matrices were created: one for the criteria (Table 1) and six for the sub-criteria (Table 2), using an evaluation scale divided into nine levels, where level 1 represents equal importance between factors, and level 9 represents nine times more importance of one factor compared to another. For example, Status was considered 3 times more important than Water Input $(1 / 3=0.33), 5$ times more important that Water Source $(1 / 5=0.20), 7$ times more important than Access and Distance to Pollution Source $(1 / 7=0.14)$, which means that these two criteria have the same importance, and 9 times more important than Adjacency to Aquaculture farms $(1 / 9=0.11)$ (Table 1$)$.

Since the numeric values are derived from the subjective preferences of individuals, some inconsistencies in the final matrix of judgments are expected (Mu and Pereyra-Rojas, 2017). The question is how much inconsistency is acceptable. For this purpose, AHP calculates a consistency ratio (CR) comparing the consistency index (CI) of the matrix in question versus the consistency index of a random-like matrix (RI) (Mu and Pereyra-Rojas, 2017). Saaty (2012) has shown that a consistency ratio (CR) of 0.10 or less is acceptable to continue the AHP analysis.

From the paired comparisons (Tables 1 and 2), a scale of priorities was established, multiplying the weight of the criteria by the weight of its sub-criteria. For example, the rank of Status/Inactive farms was established multiplying the weight of Status by the weight of Inactive farms. The results provided a ranked list of factors.

For decision-making purposes, a long list of suitability ranks is unmanageable. To simplify the process of decision, all potential areas were classified within intervals of recommendation for aquaculture development. To determine the intervals of recommendation, the Equal Intervals Method was applied defining a priori five classification intervals: highly recommended, very recommended, recommended, little recommended and very little recommended. The distance between classification intervals $(D)$ was calculated following Eq. (1).

$D=(H+L) / 5$

where $H$ is the highest rank value and $L$ is the lowest rank value.

\subsubsection{Calculating the physical carrying capacity}

The physical carrying capacity was calculated summing the area of active aquaculture farms to ponds with priority 1 (highly recommended), 2 (very recommended) and 3 (recommended). Ponds
Table 2

Pairwise comparison matrix for the sub-criteria.

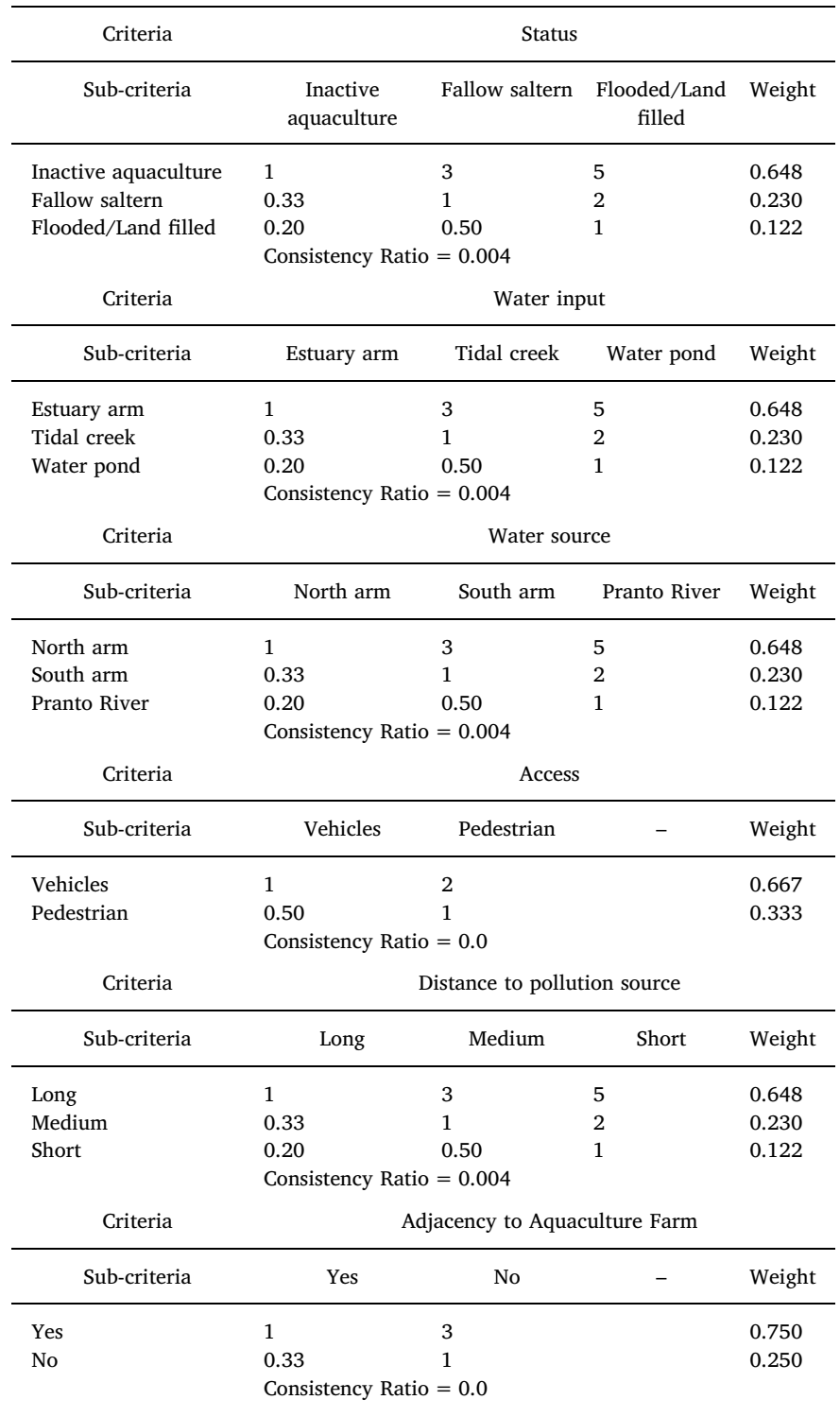

with a priority above 3 were considered unsuitable for the development of aquaculture. The physical carrying capacity was calculated for scenarios 1 and 2 (Fig. 2).

\subsubsection{Assessing aquaculture provisioning ecosystem services}

One of the main goals of the integrated management plan of the Salgado is the provision of aquaculture products. Gilthead seabream (Sparus aurata) and Bass (Dicentrarchus labrax) are the main species 
produced in the Salgado of the Figueira da Foz and therefore are the main provisioning ecosystem services provided by aquaculture. According to FAO, the average production $\left(\mathrm{kg} \mathrm{ha}^{-1} \mathrm{yr}^{-1}\right)$ for semi-intensive aquaculture varies between 500 and $2400 \mathrm{~kg} \mathrm{ha}^{-1} \mathrm{yr}^{-1}$ for Sparus aurata (FAO, 2005b), and between 500 and $700 \mathrm{~kg} \mathrm{ha}^{-1} \mathrm{yr}^{-1}$ for Dicentrarchus labrax (FAO, 2005a). An estimate of the contribution of the Salgado ecosystem to the value of provisioning services from aquaculture was calculated $\left(\mathrm{kg} \mathrm{yr}^{-1}\right)$ determining the minimum $\left(500 \mathrm{~kg} \mathrm{ha}^{-1} \mathrm{yr}^{-1}\right)$ and the maximum $\left(2400 \mathrm{~kg} \mathrm{ha}^{-1} \mathrm{yr}^{-1}\right.$ ) average production, based on a) the current situation of the Salgado of the Figueira da Foz, b) the physical carrying capacity, given the current situation (scenario 1) and on a) the physical carrying capacity, given an alternate scenario of active aquaculture farms (scenario 2). Comparing situations a) and b) with the current situation provides an estimate of the change in value generated by variations in spatial allocation (Fezzi et al., 2011).

\section{Results}

\subsection{Current situation}

The assessment of the current situation indicates that the Salgado has a total of 30 aquaculture farms, of which 19 are active and 11 are inactive (Table 3, Appendice A). The activity is dominated by fish farms, in a semi-intensive regime, of gilthead seabeam (Sparus aurata) and bass (Dicentrarchus labrax). The majority of the farms are located in the Morraceira island, occupying a total area of 229.51 ha (Fig. 3).

The current salt production area is currently distributed throughout a total of 58 saltworks encompassing 161 salterns, which occupy a total area of 358.40 ha (Fig. 3). Of these, 53 are active, 80 are fallow and 28 are flooded or land filled (Table 4).

\subsection{Ranked list of physical factors}

The suitability of potential areas for aquaculture development was determined based on the rank list provided in Table 5. Satus was considered the criteria with the highest relevance (Table 1) and thus it was assigned the highest weight (Table 5). Adjacency to aquaculture farms was considered the least relevant criteria (Table 1) and thus it was assigned the lowest weight (Table 5). Criteria and sub-criteria with higher ranks are preferred for aquaculture development.

When summing the rank priorities, the rate of each pond is obtained. The results indicate that inactive farms (0.319), with water input from an estuary arm (0.45), preferentially from the North arm (0.078), with vehicle access (0.043), distant from the polluting point $(0.041)$ and adjacent to an aquaculture (0.028) are the most suitable ponds for aquaculture development (0.654) (Table 5). On the other hand, fallow salterns (0.060), with water input from water ponds (0.027) originating from the Pranto river (0.015), with pedestrian access (0.021), close to polluting points $(0.008)$ and not adjacent to active aquaculture farms (0.009) are the least suitable ponds for aquaculture development (0.140) (Table 5).

After summing all possible alternatives, they were classified into

Table 3

Number of aquaculture farms and occupied area, per region of the Salgado of the Figueira da Foz and per status.

\begin{tabular}{lllllll}
\hline \multirow{2}{*}{ Salgado region } & \multicolumn{2}{l}{ Active } & \multicolumn{2}{l}{ Inactive } & \multicolumn{2}{l}{ Total } \\
\cline { 2 - 7 } & $\mathrm{Nr}$ & Area (ha) & $\mathrm{Nr}$ & Area (ha) & $\mathrm{Nr}$ & Area (ha) \\
\hline Vila Verde & 0 & 0.00 & 0 & 0.00 & 0 & 0.00 \\
Morraceira & 13 & 108.54 & 7 & 37.85 & 20 & 146.39 \\
Lavos & 6 & 69.29 & 4 & 13.83 & 10 & 83.12 \\
Total & $\mathbf{1 9}$ & $\mathbf{1 7 7 . 8 3}$ & $\mathbf{1 1}$ & $\mathbf{5 1 . 6 8}$ & $\mathbf{3 0}$ & $\mathbf{2 2 9 . 5 1}$ \\
\% & $\mathbf{6 3}$ & $\mathbf{7 7 . 4 8}$ & $\mathbf{3 7}$ & $\mathbf{2 2 . 5 2}$ & $\mathbf{1 0 0}$ & $\mathbf{1 0 0}$ \\
\hline
\end{tabular}

one of five classification levels, providing a manageable scale of priorities (Table 6). Considering the Equal interval method, the difference between the intervals is 0.103 . According to the classification levels, the most suitable ponds for aquaculture have priority 1 (highly recommended), whereas the least suitable ponds have priority 5 (very little recommended).

\subsection{Physical carrying capacity}

Scenario 1 indicates an aquaculture physical carrying capacity of 37 suitable ponds occupying a total area of 267.55 ha (Table 7). Scenario 2 , which considers Inactive farms as active, indicates an aquaculture physical carrying capacity of 59 suitable ponds, occupying a total area of 364.84 ha. The spatial allocation scenarios differ among the two situations (Fig. 4).

\subsection{Aquaculture provisioning services}

An estimate of the contribution of the Salgado ecosystem to the value of provisioning services from aquaculture regarding the current situation and the two scenarios developed is available in Table 8. The results indicate that the current production within the Salgado may increase up to 642.12 tonns/year in the scenario 1 and 875.62 tonns/ year in the scenario 2 .

\section{Discussion}

This study used the AHP method to select suitable areas for inland aquaculture development in a coastal area dominated by salt work production ponds. In particular it provided allocation scenarios from which the physical carrying capacity for aquaculture development was calculated and it quantified the value of provisioning ecosystem services from aquaculture generated by variations in spatial allocation. This study differs from previous MCDM analyses applied to aquaculture for site selection since it focuses on the potential physical space but considers physical factors relevant to two competing activities: aquaculture and salt production. Other known studies have also considered ecological and socio-economic factors relevant to determine the physical available space, but have not taken into consideration the competition among activities for the same physical factors (Septriani et al., 2015; Silva et al., 2011).

Evaluations of the aquaculture sector performance (Hofherr et al., 2012; EC, 2013; STECF, 2014) indicate that competition for space has been hindering aquaculture development. This study demonstrated that coastal inland aquaculture has the potential to increase taking advantage of a decreasing solar salt production sector. In our case study, only $33 \%$ of the remaining salterns are currently actively producing salt and the decreasing tendency has been observed in other regions of Portugal (Rodrigues et al., 2011), Europe (Kortekaas, 2004) and other regions of the world (Mani et al., 2012; Wang et al., 2015). However, negotiating aquaculture space demands in saltscapes will remain crucial as property rights regarding saltworks are historically established. In our case study, to this issue adds the problem of unknown ownership since the property of several abandoned saltworks is yet to be unveiled due to obstacles related to historical property rights, unknown heirs and/or unconcerned heirs. Space demands negotiation will also be important as solar saltworks are increasingly seen as contributing to the amenity value of coastal landscapes (Crisman et al., 2009; Korovessis and Lekkas, 2009; Korovessis et al., 2014; Balsas, 2016), in contrast to aquaculture which, though contributing to the value of provisioning services (Smith et al., 2010), is seen as negatively contributing to the value of regulating and cultural services (Martínez-Porchas and Martínez-Cordova, 2012; Schmitt and Brugere, 2013; Dalton et al., 2017). In our case study, aquaculture farms are already coexisting with salt production ponds and the number of salterns converted to farms is expected to increase, but local authorities are recognizing the value of 


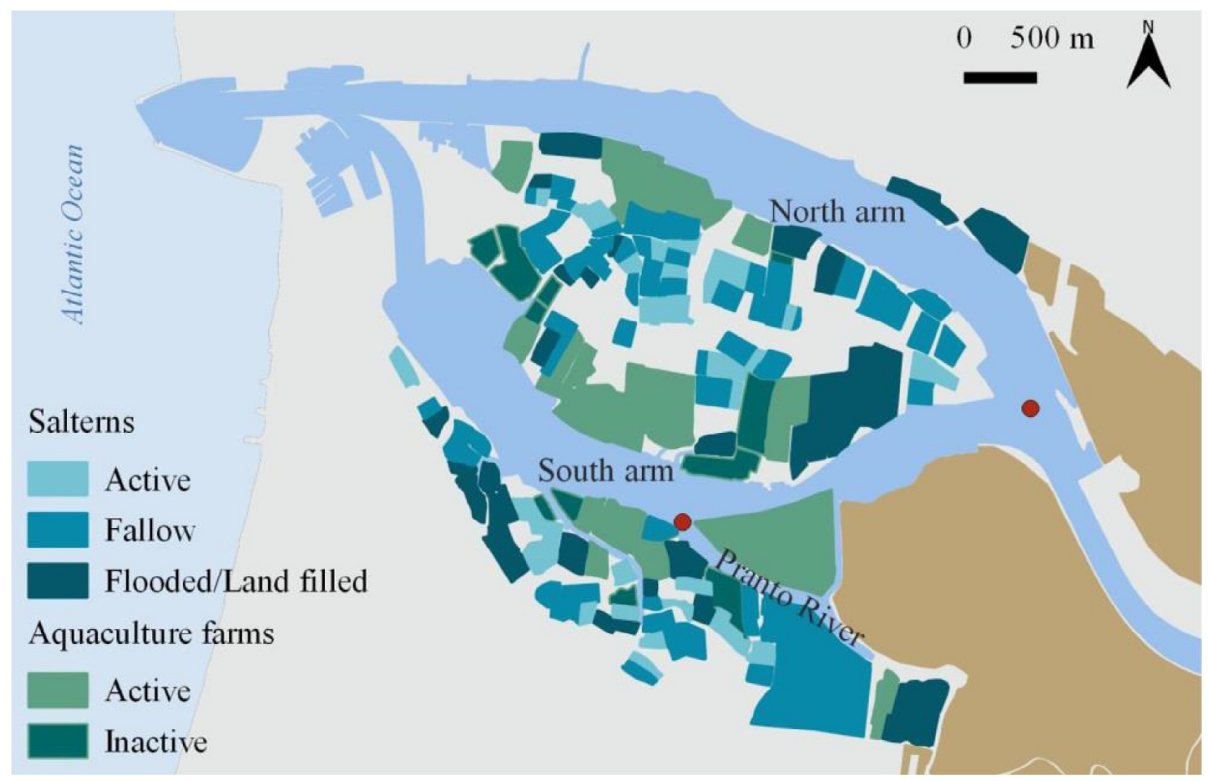

Fig. 3. Current situation. Status of salterns and aquaculture farms in the Salgado of the Figueira da Foz.

saltwork rehabilitation as a mean to enhance environmental conservation, promote tourism and safeguard cultural heritage. As such, to select suitable sites for aquaculture development and calculate the physical carrying capacity, in this study, salterns were considered both a landscape opportunity and a constraint. An opportunity because salterns, in the Mondego estuary, are the only available physical space for inland aquaculture development; and a constraint because local authorities consider that the conversion of all salterns to aquaculture is not admissible.

One factor that stands out from the analysis is that most of the ponds suitable for aquaculture (priority 1,2 and 3) find their space in inactive farms and flooded/land filled salterns, adjacent to one of the estuary arms (water input: estuary, and water source: north and south arms), validating the weights assigned to these criteria during the AHP process. The distance to pollution sources, the access through vehicle and the adjacency to an active farm are not so evident in the allocation scenarios, but in the end, lower weights were attributed to these criteria and thus a lesser importance in determining spatial allocation was expected. The location of the most recommended ponds for aquaculture will contribute to minimize the conflicts between aquaculture and salt production because: 1) the model privileges inactive farms and flooded/land filled salterns, leaving fallow salterns available for saltwork rehabilitation. Fallow salterns are in higher number and their rehabilitation is expected to give higher economic revenue to saltworkers in a shorter period due to lower investment costs for reactivation. 2) Also privileges farms capturing water directly from the estuary, instead from tidal creeks and water ponds, reducing competition for water; and 3) privileges potential locations adjacent to active farms reducing the probability of damaging the saltern's protective structures ("motas"). 4) Finally, most of the recommended farms are
Table 5

Rank list of criteria and sub-criteria.

\begin{tabular}{lll}
\hline Criteria & Sub-criteria & Rank priorities \\
\hline Status & Inactive farms & 0.319 \\
& Flooded/land filled saltern & 0.113 \\
& Fallow saltern & 0.06 \\
Water input & Estuary arm & 0.145 \\
& Tidal creek & 0.052 \\
Water source & Water pond & 0.027 \\
& North arm & 0.078 \\
Access & South arm & 0.028 \\
& Pranto river & 0.015 \\
Distance to pollution source & Vehicles & 0.043 \\
& Pedestrian & 0.021 \\
& Long & 0.041 \\
Adjacency to aquaculture farms & Medium & 0.015 \\
& Short & 0.008 \\
& Yes & 0.028 \\
& No & 0.009 \\
\hline
\end{tabular}

Table 6

Classification levels.

\begin{tabular}{lll}
\hline Priority & Levels & Interval \\
\hline Priority 1 & Highly recommended & 0.654 a 0.552 \\
Priority 2 & Very recommended & 0.552 a 0.449 \\
Priority 3 & Recommended & 0.449 a 0.346 \\
Priority 4 & Little recommended & 0.346 a 0.243 \\
Priority 5 & Very little recommended & 0.243 a 0.103 \\
\hline
\end{tabular}

Table 4

Number of salterns and occupied area, per region of the Salgado of the Figueira da Foz and per status.

\begin{tabular}{|c|c|c|c|c|c|c|c|c|}
\hline \multirow[t]{2}{*}{ Salgado Region } & \multicolumn{2}{|c|}{ Active } & \multicolumn{2}{|c|}{ Fallow } & \multicolumn{2}{|c|}{ Flooded/Land filled } & \multicolumn{2}{|c|}{ Total } \\
\hline & Nr. & Area (ha) & Nr. & Area (ha) & Nr. & Area (ha) & Nr. & Area (ha) \\
\hline Vila Verde & 0 & 0.00 & 0 & 0.00 & 3 & 16.24 & 3 & 16.24 \\
\hline Morraceira & 28 & 35.03 & 64 & 97.88 & 11 & 65.22 & 103 & 198.13 \\
\hline Lavos & 25 & 30.36 & 16 & 89.70 & 14 & 50.97 & 55 & 171.03 \\
\hline Total & 53 & 65.39 & 80 & 187.58 & 28 & 132.43 & 161 & 385.40 \\
\hline$\%$ & 33 & 16.97 & 50 & 48.67 & 17 & 34.36 & 100 & 100 \\
\hline
\end{tabular}


Table 7

Aquaculture physical carrying capacity, for scenarios 1 and 2, at the Salgado of the Figueira da Foz.

\begin{tabular}{|c|c|c|c|c|}
\hline \multirow[t]{2}{*}{ Scenarios } & & \multirow[t]{2}{*}{ Nr. of Aquaculture ponds } & \multicolumn{2}{|l|}{ Area } \\
\hline & & & ha & $\%$ of Salgado \\
\hline \multirow[t]{3}{*}{ SCENÁRIO 1} & Current situation | Active farms & 19 & 177.83 & 21.04 \\
\hline & Ponds with priority 1,2 and 3 & 18 & 95.72 & 10.61 \\
\hline & Physical carrying capacity & 37 & 267.55 & 31.66 \\
\hline \multirow[t]{3}{*}{ SCENÁRIO 2} & Probable situation $\mid$ Active farms + Inactive farms & 30 & 229.51 & 27.15 \\
\hline & Ponds with priority 1,2 and 3 & 29 & 135.33 & 16.01 \\
\hline & Physical carrying capacity & 59 & 364.84 & 43.17 \\
\hline
\end{tabular}

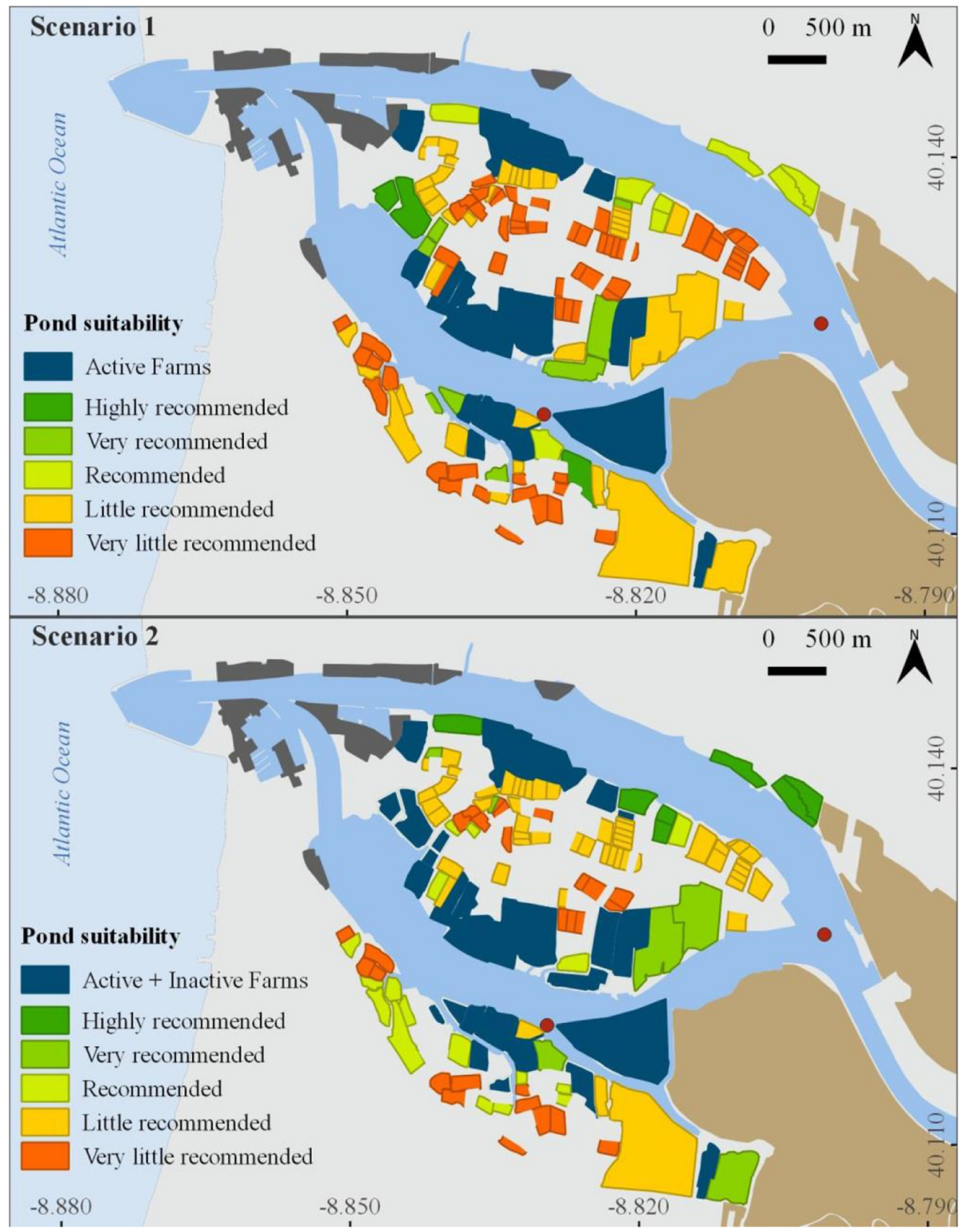

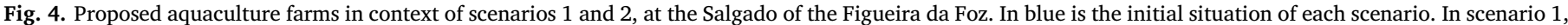

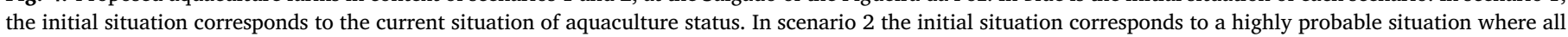
aquaculture farms (active and inactive) would be active.

adjacent to the estuary arms, again reducing pressure over the "motas" and reducing impact in salt quality due to pollution from high traffic (air pollution and dust) associated with aquaculture daily activities.

The criteria selected had two main goals: a) to guarantee the best location possible considering the water quality and access to farms (Water source, Access and Distance to pollution source) and b) to minimize the expected conflicts with salt production activities (Status, Water input and Adjacency to aquaculture farms). Although the criteria selected have environmental and social concerns into account, we considered that it was not sufficient to calculate the ecological and the social carrying capacity as defined by McKinsey et al. (2006). The Ecological carrying capacity has into account changes to ecological processes, species, 
Table 8

Aquaculture provisioning ecosystem services.

\begin{tabular}{llll}
\hline \multirow{2}{*}{ Based on } & & \multicolumn{2}{l}{ Average production (tonns/year) } \\
\cline { 3 - 4 } & & Minimum & Maximum \\
\hline Current situation & & 88.91 & 426.79 \\
Physical carrying capacity & Scenario 1 & 133.78 & 642.12 \\
& Scenario 2 & 182.42 & 875.62 \\
\hline
\end{tabular}

populations, or communities in the environment, which our approach did not account for. The Social carrying capacity, which is defined as the $\ll$ point at which alternative social uses become prohibitive due to level, density, or placement of aquaculture farms $\gg$, must quantify the value of stakeholder involvement in a science-based effort and recognize the importance of economics, for instance including the value assigned to ecosystem services. Our work includes the perception of stakeholders for the best conditions for aquaculture and salt production development, but it does not define the point at which it is not "acceptable" to allow more farms, based on stakeholder's limits. For the purpose of this work, the limit was established at farms with priority 3 , but a thorough evaluation on the tipping point at which the conversion of salterns to aquaculture farms is no longer acceptable is necessary.

The absence of data also did not allow the calculation of the production carrying capacity, defined as the maximum aquaculture production biomass dependent upon technology, production system and financial investment. As a proxy, the current and the potential aquaculture provisioning services were estimated based on the average production values for semi-intensive aquaculture provided by FAO. Expressing the value of ecosystem services, ultimately in monetary units, is a widely accepted tool to convey the importance of ecosystems and biodiversity, especially to policy makers (Groot et al., 2012; Kubiszewski et al., 2017). In our study, the change in the provisioning services' value generated by the new aquaculture farms, suggests an increase of up to $105 \%$. This positive change is a powerful policy tool to encourage potential investors in aquaculture development within saltscapes. Historically, water reservoir ponds, needed for the initial stages of salt making, have been used for extensive aquaculture without significant economic, social and/or environmental impacts (Gamito, 1997; Buestel, 2005; Santulli and Modica, 2009). In the Mondego estuary, extensive aquaculture has mainly been a residual activity for the owners of these ponds. With the decline of salt industry over the 20th century, the adaptation to extensive and semi-intensive fish farming reutilizing also the evaporation areas became a reality in countries like Portugal (Marques et al., 2017) and Spain (Yúfera and Arias, 2010). As this study demonstrates that inland aquaculture potential in the coastal system is yet to be fulfilled, the need for the development of integrated management plans, in order to guarantee the environmental, social, cultural and economic sustainability of salt landscapes, arises. More so, considering that saltscapes have also the potential to support parallel activities such as tourism, outdoor training and exploitation of flora and fauna (Crisman et al., 2009; Dias, 2009).

\section{Conclusion}

AHP is a useful tool for the selection of suitable areas for coastal pond aquaculture in a multi-use context. Coupled with GIS, it provides a methodological approach for coordinated spatial planning, as proposed by the European Commission (EC, 2013). Incorporating physical factors of social nature to estimate the physical carrying capacity for aquaculture has proven to be a successful way to account for space competition between conflicting activities.

Coupled AHP/GIS has previously been applied for aquaculture site selection, but for the first time the approach has been used for pond aquaculture development in partially abandoned saltscapes of artisanal solar salt production. As our results demonstrate the approach supports the definition of the acceptable physical limits for aquaculture development in salt landscapes, assisting decision-makers in space competition management and providing evidence of potential positive impacts on the provisioning services from aquaculture. We anticipate that combining the physical carrying capacity, incorporating social physical factors, with the social carrying capacity will lead to improvements in the definition of the acceptable social limits for aquaculture development.

\section{Conflicts of interest}

None.

\section{Acknowledgements}

This study benefited from the protocol between the Municipality of the Figueira da Foz and the University of Coimbra. The authors would like to thank the salt and aquaculture producers who provided assistance during field work.

\section{Funding}

This study was supported by the Fundação para a Ciência e Tecnologia (FCT) [strategic project UID/MAR/04292/2013 granted to the Marine and Environmental Sciences Centre (MARE)]; and the Regional Operational Programme CENTRO2020 [project CENTRO-010145-FEDER-000006].

Appendix A. Aquaculture farms in the Salgado, in 2017

\begin{tabular}{|c|c|c|c|c|}
\hline Name & Status & $\begin{array}{l}\text { Farm } \\
\text { type }\end{array}$ & Regime & Production license \\
\hline Adeiro Velho II & Active & Bivalve & Extensive & Ruditapes decussatus, Venerupis pullastra, Crassostrea spp.e Mytilus sp. \\
\hline Casa da Pedra & Active & Bivalve & NI & Ruditapes decussatus, Venerupis pullastra, Cerastoderma edule \\
\hline Torrão & Active & Fish & Extensive & Dicentrarchus labrax, Sparus aurata \\
\hline Cavadas & Active & Fish & Extensive & Dicentrarchus labrax, Sparus aurata \\
\hline Norte & Active & Fish & Semi-intensive & Sparus aurata \\
\hline Mondeguinho & Active & Fish & Semi-intensive & Sparus aurata \\
\hline Moleiras I & Active & Fish & Semi-intensive & Dicentrarchus labrax, Sparus aurata \\
\hline Adeiro Velho I & Active & Fish & Semi-intensive & Anguilla anguilla, Dicentrachus labrax, Sparus aurata \\
\hline S.Julião & Active & Fish & Semi-intensive & Dicentrarchus labrax \\
\hline Venturas de Cima & Active & Fish & Semi-intensive & Dicentrarchus labrax, Sparus aurata \\
\hline Palhinha & Active & Fish & Semi-intensive & Dicentrarchus labrax, Sparus aurata \\
\hline
\end{tabular}




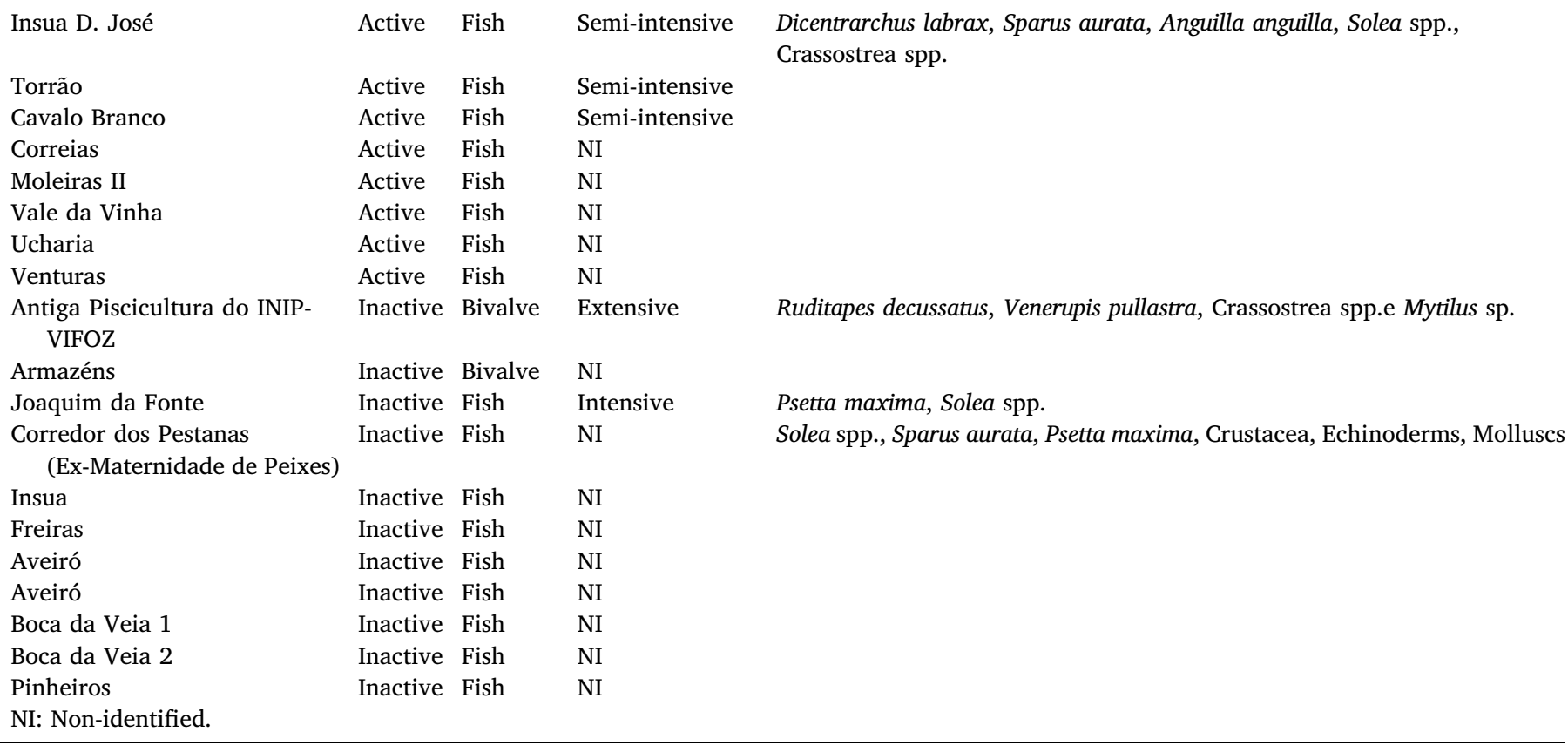

\section{References}

Altuzarra, A., Moreno-Jimenez, J.M., Salvador, M.A., 2007. Bayesian priorization procedure for AHP-group decision making. Eur. J. Oper. Res. 182 (1), 367-382. http:// dx.doi.org/10.1016/j.ejor.2006.07.025.

Amorim I., 2001. O sal de Aveiro. Breve relance histórico (sécs. XIII a XX). (1 ed., pp. 125) Arouca: Câmara Municipal de Arouca. https://sigarra.up.pt/flup/pt/pub_geral.pub_ view?pi pub base $\mathrm{id}=11062 \&$ pi pub $\mathrm{r} 1 \mathrm{id}=$.

Baeta, A., Niquil, N., Marques, J.C., Patrício, J., 2011. Modelling the effects of eutrophication, mitigation measures and an extreme flood event on estuarine benthic food webs. Ecol. Model. 222 (6), 1209-1221. http://dx.doi.org/10.1016/j. ecolmodel.2010.12.010.

Balsas, C., 2016. Mediterranean saltscapes: the need to enhance fragile ecological and cultural resources in Portugal. J. Interdiscip. Stud. Archit. Urbanism. http://dx.doi. org/10.26754/ojs zarch/zarch.201671519.

Benessaiah, K., Sengupta, R., 2014. How is shrimp aquaculture transforming coastal livelihoods and lagoons in Estero Real, Nicaragua? The need to integrate social-ecological research and ecosystem-based approaches. Environ. Manage. 54, 162-179. http://dx.doi.org/10.1007/s00267-014-0295-x.

Buestel D., 2005. History, Status and Future of Oyster Culture in France. 1st International Oyster Symposium Proceedings. https://pdfs.semanticscholar.org/d2d6/ 178356cf60e4c938535ec8320a3c9db61b7b.pdf.

Chen, M.F., Tzeng, G.H., Ding, C.G., 2008. Combining fuzzy AHP with MDS in identifying the preference similarity of alternatives. Appl. Soft Comput. 8, 110. http://dx.doi. org/10.1016/j.asoc.2006.11.007.

Chen, S.M., Wu, Y.M., Yang, L., 2014. Application of the Analytic Hierarchy Process for the selection of wastewater reuse targets. Manage. Decis. 52 (7), 1222-1235. http:// dx.doi.org/10.1108/MD-11-2012-0794.

Coelho, J.P., Flindt, M.R., Jensen, H.S., Lillebø, A.I., Pardal, M.A., 2004. Phosphorous speciation and availability in intertidal sediments of a temperate estuary: relation to eutrophication and annual P-fluxes. Estuarine, Coastal, Shelf Sci. 61, 583-590. http://dx.doi.org/10.1016/j.ecss.2004.07.001.

Coelho R.J.D., Hilário M.R.C., Duarte D.N.R., 2015. Solar Salt Works Integrated Management. Solar Salt Works \& The Economic Value of Biodiversity. Proceedings of the International Conference. 4th June 2014, Trapani, Sicily. file:///C:/Users/IMAR/ Downloads/Proceedingsofthe2014EuSaltSolarSaltConference.pdf.

Communities and Local Government, 2009. Multi-criteria analysis: a manual. Department for Communities and Local Government, London.

Cordeiro A.M.R. and Paredes L.C., 2013. Valorização turística da ilha da Morraceira (Município da Figueira da Foz: novas utilizações do potencial endógeno do estuário do Mondego. Cadernos de Geografia n ${ }^{\circ} 32$. Coimbra, FLUC. 229-238 pp.

Crisman T.L., 2000. Conservation of Mediterranean coastal saline ecosystems: The private sector role in maintaining ecological function (pp. 39-48). In: Korovessis, Nicholas and Themistokles Lekkas. Eds. Saltworks: Preserving saline coastal ecosystems Proceedings of the Post-Conference Symposium of the 6th International Conference on Environmental Science and Technology, Athens, 2000, p. 39.

Crisman, T.L., Takavakoglou, V., Alexandridis, T., Antonopoulos, V., Zalidis, G., 2009. Rehabilitation of abandoned saltworks to maximize conservation, ecotourism and water treatment potential. Global NEST J. 11 (1), 24-31.

Dalton, T., Jin, D., Thompson, R., Katzanek, A., 2017. Using normative evaluation to plan for and manage shellfish aquaculture development in Rhode Island coastal waters.
Mar. Policy 83, 194-203. http://dx.doi.org/10.1016/j.marpol.2017.06.010.

Davis J.S. 1999. Solar Saltworks - An environmentally friendly industry. Post-Conference Oral Contribution. Pythagorion Samos, Greece. http://conferences.gnest.org/ Conferences/Saltworks_post/031-037.pdf.

Davis, J.S., 2000. Structure, function, and management of the biological system for seasonal solar saltworks. Global NEST: Int. J. 2 (3), 217-226. https://journal.gnest.org/ sites/default/files/Journal\%20Papers/davis.pdf.

Dias, M.P., 2009. Use of salt ponds by wintering shorebirds throughout the tidal cycle. Waterbirds 32 (4), 531-537. http://dx.doi.org/10.1675/063.032.0406.

Dolbeth, M., Cardoso, P.G., Ferreira, S.M., Verdelhos, T., Raffaelli, D., Pardal, M.A., 2007. Anthropogenic and natural disturbance effects on a macrobenthic estuarine community over a 10-year period. Mar. Pollut. Bull. 54, 576-585. http://dx.doi.org/10. 1016/j.marpolbul.2006.12.005.

EC, 2009. Green Paper on Reform of the Common Fisheries Policy. COM(2009)163 final.

EC, 2012. Blue Growth opportunities for marine and maritime sustainable growth: communication from the Commission to the European Parliament, the Council, the European Economic and Social Committee and the Committee of the Regions. In: European Commission, Brussels (Ed.) p.12.

EC, 2013. Strategic Guidelines for the sustainable development of EU aquaculture: communication from the Commission to the European Parliament, the Council, the European Economic and Social Committee and the Committee of the Regions. In: European Commission, Brussels (Ed.) Fisheries, p.12.

Falconer, L., Hunter, D.-C., Telfer, T.C., Ross, L.G., 2013. Visual, seascape and landscape analysis to support coastal aquaculture site selection. Land Use Policy 34, 1-10. http://dx.doi.org/10.1016/j.landusepol.2013.02.002.

Falconer, L., Telfer, T.C., Ross, L.G., 2016. Investigation of a novel approach for aquaculture site selection. J. Environ. Manage. 181, 791-804. http://dx.doi.org/10.1016/ j.jenvman.2016.07.018.

FAO, 1984. Inland Aquaculture Engineering. ADCP/REP/84/21. United Nations Development Programme. Food and Agriculture Organization of the United Nations. http://www.fao.org/docrep/x5744e/x5744e00.htm\#Contents.

FAO, 2005. Cultured Aquatic Species Information Programme. Dicentrarchus labrax. Cultured Aquatic Species Information Programme. Text by Bagni, M. In: FAO Fisheries and Aquaculture Department [online]. Rome. Updated 18 February 2005. [Cited 30 April 2018].

FAO, 2005. Cultured Aquatic Species Information Programme. Sparus aurata. Cultured Aquatic Species Information Programme. Text by Colloca, F., Cerasi, S. In: FAO Fisheries and Aquaculture Department [online]. Rome. Updated 8 February 2005. [Cited 30 April 2018].

FAO, 2010. Aquaculture development. 4. Ecosystem approach to aquaculture. FAO Technical Guidelines for Responsible Fisheries. No. 5, Suppl. 4. Rome, p.53.

Fezzi C, Crowe A, Abson D, Bateman I, Askew T, Munday P, Pascual U, Sen A, Darnell A, Haines-Young R., 2011. Evaluating provisioning ecosystem service values: a scenario analysis for the United Kingdom. Report to the Economics Team of the UK National Ecosystem Assessment. Availabel at: http://uknea.unep-wcmc.org/LinkClick.aspx? fileticket $=$ h2WCf1 fOqNk\%3D\&tabid $=82$.

Flindt, M.R., Kamp-Nielsen, L., Marques, J.C., Pardal, M.A., Bocci, M., Bendoricchio, G., Salomonsen, J., Nielsen, S.N., Jørgensen, S.E., 1997. Description of the three shallow estuaries: Mondego River (Portugal), Roskilde Fjord (Denmark) and the Lagoon of Venice (Italy). Ecol. Model. 102, 17-31. http://dx.doi.org/10.1016/S0304-3800(97) 00092-6.

Gamito, S., 1997. Sustainable management of a coastal lagoonal system (Ria Formosa, 
Portugal): an ecological model for extensive aquaculture. Int. J. Salt Lake Res. 6, 145-173.

Gentry, R.R., Lester, S.E., Kappel, C.V., White, C., Bell, T.W., Stevens, J., Gaines, S.D., 2016. Offshore aquaculture: spatial planning principles for sustainable development Ecol. Evol. 7 (2), 733-743. http://dx.doi.org/10.1002/ece3.2637.

Gimpel, A., Stelzenmüller, V., Töpsh, S., Galparsoro, I., Gubbins, M., Miller, D., Murillas, A., Murray, A.G., Pinarbasi, K., Roca, G., Watret, R., 2018. A GIS-based tool for an integrated assessment of spatial planning trade-offs wit aquaculture. Sci. Total Environ In Press.

Goepel, K.D., 2017. BPMSG's AHP Online System. June, 2017. In http://bpmsg.com/ academic/.

Groot, R., Brander, L., van der Ploeg, S., Costanza, R., Bernard, F., Braat, L., Christie, M., Crossman, N., Ghermandi, A., Hein, L., Hussain, S., Kumar, P., McVittie, A., Portela, R., Rodriguez, L.C., ten Brink, P., van Beukering, P., 2012. Global estimates of the value of ecosystems and their services in monetary units. Ecosyst. Serv. 1, 50-61. http://dx.doi.org/10.1016/j.ecoser.2012.07.005.

Hall, C., McVittie, A., Moran, D., 2004. What does the public want from agriculture and the countryside? A review of evidence and methods. J. Rural Stud. 20, 211-225. http://dx.doi.org/10.1016/j.jrurstud.2003.08.004

Henriques, N.S., Monteiro, P., Bentes, L., Oliveira, F., Afonso, C.M.L., Gonçalves, J.M.S., 2017. Marxan as a zoning tool for development and economic purposed areas aquaculture management areas (AMAs). Ocean Coastal Manage. 141, 90-97. http:// dx.doi.org/10.1016/j.ocecoaman.2017.03.016.

Hofherr J, Natale F, Fiore G., 2012. An Approach Towards European Aquaculture Performance Indicators. Indicators for Sustainable Aquaculture in the European Union. Joint Research Centre. Report EUR 25557 EN. http://dx.doi.org/10.2788/ 56181.

Hofherr, J., Natale, F., Trujillo, P., 2015. Is lack of space a limiting factor for the development of aquaculture in EU coastal areas? Ocean Coastal Manage. 116, 27-36. http://dx.doi.org/10.1016/j.ocecoaman.2015.06.010.

Hossain, M.S., Chowdhury, S.R., Das, N.G., Sharifuzzaman, S.M., Sultana, A., 2009. Integration of GIS and multicriteria decision analysis for urban aquaculture development in Bangladesh. Landscape Urban Plann. 90, 119-133. http://dx.doi.org/10. 1016/j.landurbplan.2008.10.020.

INE 2017. Estatísticas da Pesca 2016. Instituto Nacional de Estatística https://www.ine pt/ngt_server/attachfileu.jsp?look_parentBoui $=294902455 \&$ att_display $=$ n\&att download $=y$.

Inglis G.J., Hayden B.J., Ross A.H., 2000. An Overview of Factors Affecting the Carrying Capacity of Coastal Embayments for Mussel Culture. NIWA, Christchurch. Client Report CHC00/69: vi + 31 p.

Kenov, A.K., Garcia, A.C., Neves, R., 2012. Residence time of water in the Mondego estuary (Portugal). Estuar. Coast. Shelf Sci. 106, 13-22. http://dx.doi.org/10.1016/j. ecss.2012.04.008.

Kortekaas K.H., 2004. Sustainable tourism initiatives in European saltscapes In: Sustainable Tourism, FD Pineda, CA Brebbia \& Mugica M (Editors).

Korovessis, N.A., Lekkas, T.D., 2009. Solar saltworks' wetland function. Global NEST J. 11 (1), 49-57.

Korovessis N.A., Pnevmatikatos S., Georgiadis G., 2014. Solar Saltworks. A Multiexploitable -Profitable Land. Solar Salt Conference. 3rd and 4th June 2014, Trapani, Sicily.

Kubiszewski, I., Costanxza, R., Anderson, S., Sutton, P., 2017. The future value of ecosystem services: global scenarios and national implications. Ecosyst. Serv. 26, 289-301. http://dx.doi.org/10.1016/j.ecoser.2017.05.004.

Latinopoulos, D., Konstantinou, Z., Krestenitis, Y., 2012. Simulation and multicriteria analysis in sustainable coastal planning: the case of aquaculture in Thermaikos Gulf, Greece. Environ. Dev. Sustainable 12, 1027-1045. http://dx.doi.org/10.1007/ s10668-012-9370-8.

Lembo, G., Jokumsen, A., Spedicato, M.T., Facchini, M.T., Bitetto, I., 2018. Assessing stakeholders' experience and sensitivity on key issues for the economic growth of organic aquaculture production. Mar. Policy 87, 84-93. http://dx.doi.org/10.1016/j. marpol.2017.10.005.

Li, Y., Liu, H., Zhou, W., 2016. Evaluation of water resources carrying capacity based on data mining and AHP method. RISTI (Revista Iberica de Sistemas e Tecnologias de Informacao) E8, 93-106.

Lillebø, A.I., Neto, J.M., Martins, I., Verdelhos, T., Leston, S., Cardoso, P.G., Ferreira, S.M., Marques, J.C., Pardal, M.A., 2005. Management of a shallow temperate estuary to control eutrophication: the effect of hydrodynamics on the system nutrient loading. Estuar. Coast. Shelf Sci. 65, 697-707. http://dx.doi.org/10.1016/j.ecss. 2005.07.009.

Mamat N., Rasan A.R.A., Adnan N.A., Abdullah I.C., 2014. GIS-based multi-criteria decision making system for determining potential site of oyster aquaculture in Terengganu. In: IEEE 10th International Colloquium on Signal Processing \& its Applications (CSPA2014). 7-9 Mac. 2014, Kuala Lumpur, Malaysia.

Mani, K., Salgaonkar, B.B., Das, D., Bragança, J.M., 2012. Community solar salt production in Goa India. Aquat. Biosyst. 8, 30 .

Marques, L., Carriço, A., Bessa, F., Gaspar, R., Neto, J.M., Patrício, J., 2013. Response of intertidal macrobhentic communities and primary producers to mitigation measures in a temperate estuary. Ecol. Ind. 25, 10-22. http://dx.doi.org/10.1016/j.ecolind. 2012.08.022.

Marques, J.C., Teixeira, Z., Marques, C., Mota, J.C., Pinto, S., Garcia, A.C., 2017. Avaliação Integrada, Ecológica e Sociocultural da Figueira da Foz na perspetiva do desenvolvimento sustentável. Technical Report. Câmara Municipal da Figueira da Foz. p. 116

Martínez-Porchas, M., Martínez-Cordova, L.R., 2012. World aquaculture: environmental impacts and troubleshooting alternatives. Sci. World J. http://dx.doi.org/10.1100/ 2012/389623. 12:9.
Martins, I., Pardal, M.A., Lillebø, A.I., Flindt, M.R., Marques, J.C., 2001. Hydrodynamics as a major factor controlling the occurrence of green macroalgal blooms in a eutrophic estuary: a case study on the influence of precipitation and river management. Estuarine, Coastal Shelf Sci. 52, 165-177. http://dx.doi.org/10.1006/ecss.2000. 0708.

Mau-Crimmins, T., de Steiguer, J.E., Dennis, D., 2005. AHP as a means for improving public participation: a pre-post experiment with university students. For. Policy Econ. 7, 501-514. http://dx.doi.org/10.1016/j.forpol.2003.08.001.

McKindsey, C.W., Thetmeyer, H., Landry, T., Silvert, W., 2006. Review of recent carrying capacity models for bivalve culture and recommendations for research and management. Aquaculture 261 (2), 451-462. http://dx.doi.org/10.1016/j.aquaculture. 2006.06.044.

Mendoza, G.A., Martins, H., 2006. Multi-criteria decision analysis in natural resource management: a critical review of methods and new modelling paradigms. For. Ecol. Manage. 230, 1-22. http://dx.doi.org/10.1016/j.foreco.2006.03.023.

Micael, J., Costa, A.C., Aguiar, P., Medeiros, A., Calado, H., 2015. Geographic informations system in a multi-criteria tool for mariculture site selection. Coastal Manage. 43, 52-66. http://dx.doi.org/10.1080/08920753.2014.985178.

Morgan, R., 2017. An investigation of constraints upon fisheries diversification using the Analytic Hierarchy Process (AHP). Mar. Policy 86, 24-30. http://dx.doi.org/10. 1016/j.marpol.2017.05.037.

Mu, E., Pereyra-Rojas, M., 2017. Understanding the Analytic Hierarchy Process. In: Practical Decision Making. SpringerBriefs in Operations Research. Springer, Cham. http://dx.doi.org/10.1007/978-3-319-33861-3_2.

Otero, M., Coelho, J.P., Rodrigues, E.T., Pardal, M.A., Santos, E.B.H., Esteves, V.I., Lillebø, A.I., 2013. Kinetics of the PO4-P adsorption onto soils and sediments from the Mondego estuary (Portugal). Mar. Pollut. Bull. 77, 361-366. http://dx.doi.org/10. 1016/j.marpolbul.2013.08.039.

Paéz-Osuna, F., 2001. The environmental Impact of shrimp aquaculture: causes, effects, and mitigating alternatives. Environ. Manage. 28 (1), 131-140. http://dx.doi.org/10 $1007 / \mathrm{s} 002670010212$

Petanidou, T., Dalaka, A., 2009. Mediterranean's changing saltscapes: a study of the abandonment of salt-makinig business in Greece. Global NEST J. 11 (4), 415-433.

Popescu I., 2010. Fisheries in Sicily. Policy Department B: Structural and Cohesion Policies. European Parliament. http://www.europarl.europa.eu/RegData/etudes/ note/join/2010/431596/IPOL-PECH_NT(2010)431596_EN.pdf.

Radiarta, I.N., Saitoh, S.-I., Miyazono, A., 2008. GIS-based multi-criteria evaluation models for identifying suitable sites for Japanese scallop (Mizuhopecten yessoensis) aquaculture in Funka Bay, southwestern Hokkaido Japan. Aquaculture 284 (1-4), 127-135. http://dx.doi.org/10.1016/j.aquaculture.2008.07.048.

Rekha, P.N., Gangadharan, R., Ravichandran, P., Mahalakshmi, Panigrahi A, Pillai, S.M., 2015. Assessment of impact of shrimp farming on coastal groundwater using Geographical Information System based Analytical Hierarchy Process. Aquaculture 448, 491-506. http://dx.doi.org/10.1016/j.aquaculture.2015.06.025.

Robins, E.S., 2004. The Analytic Hierarchy Process. In: Roy, R. (Ed.), Strategic Decision Making. Decision Engineering. Springer, London.

Rodrigues, C.M., Bio, A., Amat, F., Vieira, N., 2011. Artisanal salt production in Aveiro/ Portugal - an ecofriendly process. Saline Syst. 7, 3.

Ross L.G., Telfer T.C., Falconer L., Soto D., Aguilar-Manjarrez J., Asmah R., Bermúdez J., Beveridge M.C.M., Byron C.J., Clément A., Corner R., Costa-Pierce B.A., Cross S., De Wit M., Dong S., Ferreira J.G., Kapetsky J.M., Karakassis I., Leschen W., Little D., Lundebye A-K., Murray F.J., Phillips M., Ramos L., Sadek S., Scott P.C., Valle-levinson A., Waley D., White P.G., Zhu C., 2013. Carrying capacities and site selection within the ecosystem approach to aquaculture. In: Ross L.G., Telfer T.C., Falconer L., Soto D., Aguilar-Manjarrez J., eds. Site selection and carrying capacities for inland and coastal aquaculture, pp. 19-46. FAO/Institute of aquaculture, University of Stirling, Expert Workshop, 6-8 December 2010. Stirling, the United Kingdom of Great Britain and Northern Ireland. FAO Fisheries and Aquaculture Proceedings No. 21. Rome, FAO. $282 \mathrm{pp}$.

Saaty, T.L., Vargas, L.G., 1991. Prediction, Projection and Forecasting. Kluwer Academic Publichers, Dordrecht.

Saaty, T.L., 1980. The Analytic Hierarchy Process, ed. McGraw-Hill, New York.

Saaty, T.L., 1990. How to make a decision: the analytic hierarchy process. Eur. J. Oper. Res. 48 (1), 9-26.

Saaty, T.L., 1996. Decision Making with Dependence and Feedback: The Analytic Network Process. RWS Publications, Pittsburgh.

Saaty, T.L., 2012. Decision Making for Leaders: The Analytic Hierarchy Process for Decisions in a Complex World, third ed. RWS Publications, Pittsburgh.

Sadoul N., Walmsley J.G., Charpentier B., 1998. Salinas and nature conservation (Conservation of Mediterranean Wetlands No.9). Arles, France: Tour du Valat.

Santulli, A., Modica, A., 2009. Aquaculture in Sicily: the state of the art. Ital. J. Anim. Sci. 8 (sup2), 829-838. http://dx.doi.org/10.4081/ijas.2009.s2.829.

Schmitt, L.H.M., Brugere, C., 2013. Capturing ecosystem services, stakeholders' preferences and trade-offs in coastal aquaculture decisions: a bayesian belief network application. PLoS ONE 8 (10). http://dx.doi.org/10.1371/journal.pone.0075956.

Seekao, C., Pharino, C., 2016. Assessment of the flood vulnerability of shrimp farms using a multicriteria evaluation and GIS: a case study in the Bangpakong Sub-Basin Thailand. Environ. Earth Sci. 75, 308. http://dx.doi.org/10.1007/s12665-0155154-4.

Septriani, Indah I, Sudarmaji, Baiquni, 2015. Carrying capacity based on multi-criteria evaluation of marginal land for catfish farming in Gunungkidul Regency, Yogyakarta. Int. J. Chem., Environ. Biol. Sci. 3 (4), 295-301.

Silva, C., Ferreira, J.G., Bricker, S.B., DelValls, T.A., Martín-Díaz, M.L., Yánez, E., 2011. Site selection for shellfish aquaculture by means of GIS and farm-scale models, with an emphasis on data-poor environments. Aquaculture 318 (3-4), 444-457. http://dx. doi.org/10.1016/j. aquaculture.2011.05.033. 
Silva, N.P., Marques, C., 2016. Os recursos Hídricos e as áreas com potencial para o desenvolvimento da atividade aquícola e salícola na Região Centro. Agência Portuguesa do Ambiente I.P, ARH Centro-DHRL.

Smith, M.D., Roheim, C.A., Crowder, L.B., Halpern, B.S., Turnipseed, M., Anderson, J.L., Asche, F., Bourillón, L., Guttormsen, A.G., Khan, A., Liguori, L.A., McNevin, A., O'Connor, M.I., Squires, D., Tyedmers, P., Brownstein, C., Carden, K., Klinger, D.H., Sagarin, R., Selkoe, K.A., 2010. Sustainability and global seafood. Science 327 (5967), 784-786.

STECF, 2014. The Economic Performance of the EU Aquaculture Sector (STECF 14-18). JRC Scientific and Policy Reports. Scientific, Technical and Economic Committee for Fisheries. https://stecf.jrc.ec.europa.eu/documents/43805/839433/2014-11_STECF +14-18+- +EU + Aquaculture + sector_JRCxxx.pdf.

Sutadian, A.D., Mutiil, N., Yilmaz, A.G., Perera, B.J.C., 2017. Using the Analytic Hierarchy Process to identify parameter weights for developing a water quality index. Ecol. Ind. 75, 220-233. http://dx.doi.org/10.1016/j.ecolind.2016.12.043.

Teixeira, Z., Teixeira, H., Marques, J.C., 2014. Systematic processes of land use/land cover change to identify relevant driving forces: implications on water quality. Sci. Total Environ. 470-471, 1320-1335. http://dx.doi.org/10.1016/j.scitotenv.2013.10. 098.

Vieira, N., Bio, A., 2011. Spatial and temporal variability of wtare quality and zooplankton in an artisanal salina. J. Sea Res. 65, 293-303. http://dx.doi.org/10.1016/j. seares.2011.01.001.

Walmsley J.G., 1999. The ecological importance of Mediterranean salinas. In: Korovessis N.A. \& Lekkas TD (Eds.) Proceedings of the Post Conference Symposium SALTWORKS: Preserving saline coastal ecosystem (6th Conference on Environmental Science \& Technology, pp. 81-95). Samos, Greece: Global Nest.

Walton, M.E.M., Vilas, C., Cañate, J.P., Gonzalez-Ortegon, E., Prieto, A., van Bergeijk, S.A., Librero, M., Mazuelos, N., Le Vay, L., 2015. A model for the future: ecosystem services provided by the aquaculture activities of Veta la Palma, Southern Spain. Aquaculture 448, 382-390. http://dx.doi.org/10.1016/j.aquaculture.2015.06.017.

Wang, H., Xu, X., Zhu, G., 2015. Landscape changes and a salt production sustainable approach in the state of salt pan area decreasing on the coast of Tianjin, China. Sustainability 7, 10078-10097. http://dx.doi.org/10.3390/su70810078.

Wijenayake, K., Amarasinghe, U., De Silva, S.S., 2016. Application of a multiple-criteria decision making approach for selecting non-perennial reservoirs for culture-based fishery development: case study from Sri Lanka. Aquaculture 459, 26-35. http://dx. doi.org/10.1016/j.aquaculture.2016.03.019.

Yang W., Jin Y., Sun T., Yang Z., Cai Y., Yi Y., In Press. Trade-offs among ecosystem services in coastal wetlands under the effects of reclamation activities. Ecological Indicators. https://doi.org/10.1016/j.ecolind.2017.05.005.

Yavuz, F., Baycan, T., 2013. Use of swot and analytic hierarchy process integration as a participatory decision making tool in watershed management. Procedia Technol. 8, 134-143. http://dx.doi.org/10.1016/j.protcy.2013.11.019.

Ying, X., Zeng, G.M., Chen, G.Q., Tang, L., Wang, K.L., Huang, D.Y., 2007. Combining AHP with GIS in synthetic evaluation of eco-environment quality-a case study of Hunan Province China. Ecol. Model. 209 (2), 97-109. http://dx.doi.org/10.1016/j. ecolmodel.2007.06.007.

Yúfera, M., Arias, A.M., 2010. Traditional polyculture in "Esteros" in the Bay of Cádiz (Spain). Hopes and expectancies for the prevalence of a unique activity in Europe. Aquaculture Eur. 35 (3).

Zhang, Z., Lu, W.X., Zhao, Y., Song, W.B., 2014. Development tendency analysis and evaluation of the water ecological carrying capacity in the Siping area of Jilin Province in China based on system dynamics and analytic hierarchy process. Ecol. Model. 275, 9-21. http://dx.doi.org/10.1016/j.ecolmodel.2013.11.031.

ZIR, 2011 O Sal e a Salicultura no concelho da Figueira da Foz. Ontem, hoje, que futuro? Associação de intervenção Social e Formação. 2010-2011. 